\title{
Determinants of Capital Structure of Agricultural Firms in Kenya
}

\author{
John Brian Kinyua \\ Peter W Muriu
}

School of Economics, University of Nairobi

doi: 10.19044/esj.2017.v13n7p277 URL:http://dx.doi.org/10.19044/esj.2017.v13n7p277

\begin{abstract}
This paper contributes to the capital structure literature by investigating the determinants of capital structure of agricultural firms in Kenya, using annual data for the period 2010-2015. An empirical model to analyze the determinants was specified and estimated using both fixed and random effects estimation techniques. The estimation results provide evidence that profitability, liquidity, age and size of the firm are significant determinants of capital structure. Specifically, the results reveal a negative relationship between profitability and long term debt and a positive relationship between age of the firm and long term debt. We also established a positive influence of age on short term debt, while a negative link is evident between liquidity, the size of the firm and short term debt. The evidence adduced is important for forming credit markets policies for agricultural firms both at the macro and the micro level.
\end{abstract}

Keywords:Capital structure; leverage; tax effect; panel data

\section{Introduction}

Financial managers aim to develop an optimal capital structure that ensures profitability both for the shareholders and the firm (Hadlock, 2002). Financial managers may decide to change the capital structure composition without affecting the assets of the firm in a process referred to as capital restructuring (Brealey, et al., 2003). A company may opt to substitute one capital structure for the other, increase debt by issuing bonds and repurchasing stocks hence increasing the debt-equity ratio or issuing stock to raise funds to pay back the loans hence reducing the debt-equity ratio (Berger and Patti, 2006). This process involves a critical analysis of the sources of financing available and selection of an optimal mix that ensures the cost of capital is low and increases the firm value. 
The main objective of this study is to investigate the determinants of capital structure of agricultural firms in Kenya. Various studies have been conducted in Sub Sahara Africa on capital structure and financial performance but with conflicting conclusions. Using a panel data on all the listed firms at the Nairobi Securities Exchange (NSE) over the time period 2002-2011, Maina and Ishmail (2014) found that debt lowers firms' profitability. Abor (2005) analyzed the capital structures of different firm sizes and found that large firms have higher debt equity ratios. This is attributed to the debt tax shield that firms utilize to maximize their profits.

Several studies have arrived at inconclusive results with regard to the capital structure-profitability nexus. Using panel data to analyze 257 South African firms for the period 1998-2009, Sujay (2015) found a positive relationship between leverage and profitability. This is consistent with Fan,TitmanandTwite (2012) who established that for South African firms financial leverage affects financial performance positively. Empirical tests in the UK confirm predictions by the trade off and the pecking order theory whereby firms that are highly profitable with few investments pay a higher dividend to their shareholders (Fama and French, 2002).

There have also been concerns over the influence of liquidity on capital structure. Serghiescu and Vaidean (2014) for example conducted panel data regression analysis on 196 Romanian firms listed on the Bucharest Stock Exchange over the period 2003-2010 and established a negative relation between liquidity and capital structure. On the contrary, Sarlija and Harc (2012) using Pearson correlation coefficient on 1058 Croatian small and medium size enterprises for the financial year 2009 to determine the covariance between liquidity and leverage found a negative relationship between liquidity and capital structure. Moreover, there was a stronger relationship between short term debt and leverage compared to long term debt and capital structure. The study by Gharaibeh (2014) on the relationship between capital structure, stock returns and liquidity of 15 firms listed in the Amman Stock Exchange for the period 2009-2012found a weak relationship between liquidity and capital structure of these firms.

Firm size has also featured prominently in the literature. Huang and Ritter (2009) for example used panel data regression analysis for 1200 listed firms in China for the period 1994-2003. The estimation results revealed a positive relationship between size and leverage. This finding supports Antoniou (2008) who also found a positive relationship between size of the firm and capital structure in U.K and U.S by using panel data and a two-step GMM estimation technique. Previous studies arriving at similar findings include Mazur (2007) using multiple regressions on Polish firms listed in the Warsaw Stock Exchange for the period of 2010-2014 and Ozkan (2001) 
who formulated a partial adjustment model and used the GMM estimation for 390 UK firms over the period of 1984-1996.

Another factor that has been analyzed extensively in the literature is firm's age. Using ordinary least squares on 28 listed agricultural firms in Nigeria for the period 2005-2010, Bassey (2014) found a positive relationship between firm's age and leverage levels. This is consistent with Mac anBhaird (2010) who investigated the determinants of capital structure of 299 Irish small and medium enterprises using a generalization of Seemingly Unrelated Regression (SUR)and arrived at similar findings. Previous studies that had established a positive relationship include Abor (2005), Chen (2004), Bevan and Danbolt (2002), Hovakimian (2004) and Welch (2004).

These initial findings suggest that profitability, liquidity, age and size are the key determinants of firms' capital structure. There has however, been limited up-to-date scholarly work detailing the role of these factors on the capital structure of agricultural firms. This study seeks to bridge this gap.

Even though the government of Kenya has formulated strategies to improve the agricultural industry in Kenya as documented by the Agriculture Sector Development Strategy (ASDS, 2010-2020), it is evident that agricultural firms still face unique challenges. These firms have all tried to overcome these hurdles through cost cutting strategies and capital restructuring methods such as increasing debt or issuing new stock to raise funds for future projects. Capital structure decisions have resulted in different outcomes for different firms.

While a few studies have analyzed the determinants of capital structure of listed firms at the NSE little has been done on the factors affecting the corporate capital structure decision of listed agricultural firms in Kenya. That which applies for the other sectors may not necessarily hold for the agriculture sector. Consistent with the research problem, the following pressing issue should receive more attention: What are the determinants of capital structure of agricultural firms in Kenya?

This study makes at least three contributions to the existing literature. First, it is timely, in view of the unresolved debate on the role of financing on firm's performance. Second, understanding the key determinants of capital structure in agricultural firms will enable investors make informed decisions regarding wealth/portfolio maximization.

This paper is structured as follows. The next section describes the theoretical underpinnings. Section 3 describes the methodology which includes conceptual framework, empirical specifications, econometric approach, data and the measurements of our variables of interest. In section 4 we present the empirical results and discussions. Conclusions and policy 
suggestions are offered in the final section by pointing out some unresolved issues.

\section{Theoretical underpinnings}

Modigliani and Miller Theorem.

Pagano (2003) argued that this approach was formulated in 1958 and it advocated for capital structure irrelevance in determining firm value. Miller and Modigliani observed that the firm's value was dependent on the operating profits and future prospects of growth for the firm. High future growth prospects result in high market value and high share prices. Fan (2012) agreed that whether a firm decides to take up more debt and become a highly leveraged firm or whether it decides to have a lower debt component was completely irrelevant to the value of the firm. Bose (2010) observed that the theory was based on the assumptions that: there were no taxes, the borrowing costs were same for both investors and companies, information was symmetrical both for the investors and the companies thus reducing the chances of agency costs and investors would be rational in the decision making process, transaction costs for selling and buying shares were nonexistent, debt financing did not affect the earnings before interest and taxes (EBIT) therefore the market value of the firm is not dependent on the capital structure policy adopted by the firm.

Modigliani and Miller (1958, 1961 and 1963) devised three propositions to support their capital structure irrelevance theory. The first proposition states that the capital structure composition does not affect firm value and increasing the debt proportion to finance the assets of the firm does not increase the firm's value. This proposition argued that both the creditors and shareholders have the same priority and income gained is divided equally among them. The second proposition states that as the firm increases leverage, shareholders perceive a higher risk and a higher return thus leading to an escalation in cost of equity. An escalation in the debtequity ratio leads to a hike in cost of capital. The third proposition stated the irrelevance of the dividend policy on the firm's market value.

In a world where corporate taxes are nonexistent, the weighted average cost of capital (WACC) remains unaffected by changes in leverage levels (Copeland, 1983). However, in the real world corporate taxes exist. In the existence of corporate taxes, WACC decreases as the firms increases leverage. As firms increase their leverage ratios, the cost of equity increases because this puts the shareholders at a higher risk of bankruptcy and little residual claims as a result of paying out retained earnings to creditors, as a result of this the shareholders require higher returns for the increased risk. On the other hand, increasing leverage enables a firm to gain through the tax deductibility of interest payments. This is a corporate tax shield which means 
that taking up more debt reduces the tax payments by the firm. Alifani and Nugroho (2013) noted that firms prefer to have high debt proportions in their capital structure to benefit from the tax shield which ensures they pay fewer taxes than the unlevered firms hence increasing the value of the firm. However, how much debt a firm should take up to finance its projects still remains a complex decision of choosing the optimal leverage ratio for the firm.

Modigliani and Miller (1963) attempted to solve the leverage ratio puzzle by setting the marginal ratio to be equivalent of the average ratio which states that firms always set long run leverage targets. The market value or the net present value of the firm can therefore be determined subtracting the replacement value leverage from the reproduction value leverage. The replacement value leverage is the cost of financing the project through the purchases of plant, equipment and working capital while the reproduction value refers to the income expected from the project. According to $M \& M$, for a marginal project, the reproduction and the replacement value leverage are equal and the net present value is zero. According to Villamil (2000) Modigliani and Miller's third proposition states that the market value is unconstrained by the dividend policy. Whether a firm decides to pay higher dividends or no dividends at all, the firm's value will be unaffected by the dividend policy implemented by the firm. Stern and Chew (2003) argued that market values of firm are affected by the dividend policy and even though they acknowledged the work of Modigliani and Miller, they provided evidence that proves that movements in stock prices are affected by the capital structure decision and the dividend policies that firms implement.

Stiglitz (1969) disputed the assumptions under which the M\&M theory was based on. He pointed out that it was impossible for corporates and individuals to borrow at the same market rate and bankruptcy costs do exist. Furthermore, taxes are existent and capital markets are imperfect. Assumptions should be close to reality and most of the assumptions in the M\&M seem to be based in a control environment. In the real world individuals borrow at higher market rates than corporate organizations.

A jump in leverage ratios leads to a rise in earnings per share of stock and therefore DeMarzo (2007) disagreed with the M\&M theory which specifies that the capital structure chosen does not change the firm's value. Brealey et al. (2013) analyzed the implications of implementing the M\&M theorem and suggested that many financial firms collapsed during the global financial crisis in 2008 as a result of high leverage. Therefore, they disagreed with the theorem put forward by the M\&M theorem which suggests that capital structure decision is irrelevant and firms can take up as much debt as possible without affecting the value of the firm. 


\section{Pecking Order Theory}

Firms prefer internal financing and would rather use retained earnings to finance future projects before resorting to debt and finally equity (Myers and Majful 1984). They stated that when firms issue new equity, investors will devalue new equity issued since they believe that the new equity is overvalued. Firms will use internal funds then issue debt and when the firm exceeds the target leverage ratio they will issue new equity (Donaldson, 1961).

Abosede (2012) analyzed the assumptions put forward in the pecking order theory and added some assumptions which included: new shares must be issued to the public and not the insiders, information is asymmetrical between the shareholders and the firm's managers, cost of equity is much higher than the cost of incurring debt and managers have more knowledge on the value of the future projects. The cost of equity surpasses the cost of debt due to the probability of undervaluation by investors; therefore firms will opt to follow the pecking order.

Firms will shy away from issuing new equity and as a result they will pass out new investment opportunities to avoid the perception of overvaluation by investors. Fama and French (2002) agreed with these observations by Myers and Majful and stated that organizations with fewer investments pay higher dividends to their shareholders. This would make sense due to the fewer number of shareholders hence the cake is divided among fewer shareholders unlike a firm with a low debt-equity ratio.

The hierarchy of financial decision making policy is highly dependent on transaction costs (Baskin 1989). Firms will opt to follow the option that has the lowest costs in order to maximize profits. He analyzed the USA markets and concluded that the cost of incurring debt was much lower in those markets than the cost of equity, thus they follow the pecking order.

Huang and Ritter (2009) found out that managers want to be in control of the decision making process and will avoid the equity option because they will lose grip of financial policy formulation in the firm. The higher the number of shareholders in the firm, the lower the power they have over the decision making process. High leverage ratios and number of shareholders restricts the managerial power of financial directors, they are constrained by both the shareholders and suppliers demands and are unable to make financial decisions fast without facing bottlenecks in the process.

Managers will minimize restrictions on their financial control by using internal funds to finance investment projects first and will only proceed to source for external funds once retained earnings are inadequate to fund future projects (Lace and Bistrova, 2011). They will seek short term loans which have minimal restrictions and do not require collateral and if they still need more funds they will proceed to take up long term debt 
(Hamilton and Fox, 1998). The last option is equity financing, after all retained earnings and short and long term debt have all been used up, thus following the pecking order theory.

Short term debt reduces the risk to shareholders and increases the stock value if the covariance between net operating income and the expected future interest is positive. Firms will take up short term debt to finance future projects which are profitable and ensure that they pay back the debt and still have enough profit to distribute to the shareholders and fund future projects (Morris 1976)

Financial managers follow the pecking order theory to maintain status quo and confidence in the shareholders (Meier and Tarhan (2007). This implies that managers are in full control of funds and the decision making process and are not constrained by conditions from suppliers and creditors. It also ensures that the agents or managers perform efficiently by utilizing internal financing well and maximizing the wealth of the shareholders (Jensen and Meckling, 1976). Once a business issues equity, investors discount the value of the stocks and conclude that they are mispriced and overvalued; they perceive the firm value to be low since equity is seen as the last resort to financing of firm projects (Frank and Goyal 2007). Moreover, if firms are unable to raise funds from internal financing and debt, they will issue common stocks first before issuing preference shares to the public. Preferred shareholders are paid out first before the common shareholders once a firm becomes insolvent and must liquidate, they also demand a fixed level of return whether the financial performance is high or low (Warfield, 2007). Therefore, firms will avoid issuing preference shares due to the high cost of this type of equity.

Hijaziand Tariq (2006) outlined the limitations of the pecking order theory by pointing out that it ignores the effects of agency costs and effects of accumulating too much retained earnings, if financial managers are too keen to follow the pecking order theory, they may avoid investing retained earnings on present investment opportunities to keep the funds for future projects to avoid borrowing in the future and as a result losing out on new and lucrative investment opportunities.

\section{Trade off Theory}

The M\&M theory had certain limitations since it indicated the importance of leverage through the tax debt shield effect. However, this supports the notion that a firm can be fully financed through debt and this can lead to bankruptcy if the managers embezzle the funds in the firm. Financial controllers must analyze the cost and gains associated with leverage. Kraus and Litzenberger (1973) argued that optimal leverage ratio indicates the balance between the bankruptcy costs and tax benefits of 
accrued debt. Firms use this balancing technique to set a target debt-equity ratio and works towards reaching that target (Myers, 1984). Frank and Goyal (2004) supported that firms set a target leverage ratio and formulate policies and investment decisions that ensure the firm operates within the set target to avoid financial distress.

Financial distress is a combination of both the bankruptcy and nonbankruptcy costs (Bevan and Danbolt, 2000). Suppliers of debt or the creditors may impose disadvantageous terms of payment such as a short payback period or high interest rates on the loan; as a result this may choke the activities and decision making process of the firm (Chen, 2004). Other costs of debt include a high staff attrition rate when the staffs predict that the firm may be unable to pay back the debt and fulfill their financial obligations, or infighting between the shareholders and the decision makers of the firm as a result of increasing the leverage in the firm.

According to Copeland (1983) the gain from leverage is the difference between the value of the levered and the unlevered firm. This is the product of the corporate tax and the market value of debt. Firms must do a cost benefit analysis of debt and ensure that the debt is profitable and adds value to the firm. If the managers misuse the funds, then the gain of leverage may be eroded. He further suggested that the optimal capital structure can be achieved by considering the debt-equity ratio and the maturity of debt. Financial practitioners must consider both the amount and the maturity of debt in order to realize its true value and impact on the firm value (Miller, 1977). The mix of long term and short term debt is extremely crucial in determining the benefit of leverage.

Businesses may decide to sell back securities in order to reach their set target ratio rather than just formulating a financial policy (Leary and Roberts 2005). Firms may issue securities to the market, however, this may lead to the misconception by investors that the shares are mispriced or overvalued (Adedeji, 1998). Therefore, many financial managers may shy off from issuing new stock as a result.

The benefits of debt are difficult to realize if one considered the nondebt tax shields and personal taxes (Miller (1977). As much as firms are ready to inject more debt to benefit from the tax shield, they cannot ignore the presence of non-debt tax. Non debt tax shields including depreciation and tax credits cannot be avoided by firms and this poses a challenge in analyzing the benefit of debt.

The tradeoff theory can be further be broken down into: The static trade off theory and the dynamic trade off theory. The static trade off theory applies to firms that set the target leverage ratio during a single period of time while the dynamic theory is followed by firms which set a target 
leverage ratio and constantly adjust the target and correct deviations from the target (Bradley (1984).

Jensen and Meckling (1976) disputed the idea of a single period model and argued that firms operate in many periods and following the static model would eliminate retained earnings which exist in the real world. They observed firms set a target leverage ratio and constantly adjust its financing and operation by considering expected future stream of cash flows thus supporting the application of the dynamic trade off theory in the real world. Hennesy and Whited (2005) formulated the dynamic trade off theory to solve the shortcomings that were evident in the static model. The firm faces two major decisions relating to the amount they need for the investment and sources of funding whether internal, debt or equity. Managers will make the capital structure decision by analyzing future values of the project and their profitability. They concluded that there is no target level ratio but rather it changes with financial needs of the firm.

According to Rajan and Zingales (2005), the target leverage is not really important and highly profitable firms tend to borrow less. This is a contradiction with the earlier predictions by Meyer, since firms are expected to borrow more to take advantage of the tax debt shield. Microsoft is a good example of firms which are highly profitable but still have zero debt (Agha et al, 2014). Graham and Harvey (2001) surveyed various corporate executives and they did not show much interest in debt. They preferred to use retained earnings instead of debt despite the benefit of the tax shield effect.

\section{Market Timing Theory}

Baker and Wurgler (2002) noted that the pecking order focused on the optimal capital hierarchy while the tradeoff theory only focused on the leverage ratio that cushion firms from financial distress. They argue that both theories avoid addressing the important factor of timing that is the optimal time to make the capital structure decision and issue new stocks to the market. They developed the market timing theory with an aim of determining the optimal market timing to issue new stocks to the market. The market timing theory is founded on the assumptions that asymmetric information may vary in the stock market and management trusts the application of the market timing strategy of the stock market (Welch, 2004).

Managers are able to note the time when it is less costly to issue equity due to the high valuation of the company's stock (Lemmon et al. (2005). Managers issue new stock when the market valuation of the firm is high which leads to low cost of equity, thus increasing the wealth of present shareholders (Adedeji, 1998). Firms issue shares when the market value rises above the past market values, they issue new stock when the share prices are 
relatively high (Lucas and McDonald, 1991). The market timing of stock issue decision made by a firm has long term effects on capital structure (Baker and Wurgler, 2002). They declare that once a firm decided to implement a certain policy regarding the market timing of stock issue; it would affect the capital structure for a long period of time. Hovakimian (2004) agreed that managers issue new stock when the share prices are high, however, he disagreed that the equity market timing policy adopted by affirm had long term effects but rather the equity market timing effect on the capital structure disappeared within two years (Huang and Ritter, 2004). Firms issue new stock when the market is well informed of the company and its growth potential (Korajczyk, Lucas and McDonald (1991). Thus firms should provide accurate information about the company before issuing new stock to avoid adverse selection and moral hazard events in the firm.

Financial managers prefer to take short term debt when they expect that the long term interest rates will fall (Bancel and Mittoo, 2004). Managers who follow this decision making process are using the forward looking timing whereby they expect the long term debt interest rates to fall in the future so they can take them but in the meanwhile they take up short term debt to finance their projects as they await the future fall in the long term debt (Graham and Harvey (2001).

The market timing theory states that an equity offering will follow a period of high financial performance and positive returns (Lucas and McDonald, 1990). This is due to the attractiveness of the firm's performances and probability of stock prices going higher as a result of continued high financial performance. Financial managers time the market and issue new stock at its peak performance, however after the initial public offering, stock prices tend to fall after some time. They concluded that optimal capital structure doesn't exist because the debt equity ratio changes when managers employ the market timing strategy. Welch (2014), through the managerial inertia theory observed that managers usually let the capital structure adjust with share prices changes.

\section{Methodology}

\subsection{Conceptual framework}

Miller and Modigliani (1958) observed that the firm's value was dependent on the operating profits and future prospects of growth for the firm. High future growth prospects results in high market value and high share prices. Myers and Majful (1984) argued that firms prefer internal financing and would rather use retained earnings to finance future projects before resorting to debt and finally equity. They stated that when firms issue new equity, investors will devalue new equity issued since they believe that 
the new equity is overvalued. The main focus of trade off theory is on the leverage ratios that cushion firms from financial distress.

\section{Profitability}

Titman and Wessels (1988) suggested that firms with high earnings before interest and taxes will use retained earnings in form of profits to fund future projects and avoid debt intake thus maintaining low debt ratios. On the other hand, Scherrand and Hulburt (2001) found evidence of a positive correlation between capital structure and profitability of firms, thus implying that highly profitable firms have high debt ratios. This study therefore predicts a positive relationship between profitability and capital structure.

\section{Liquidity}

Firms which are highly liquid have high working capital, can generate more profits for the firm and therefore reduce the need of debt (Chen, 2004). Empirical evidence shows a negative correlation between liquidity and capital structure (Sarlija and Harc 2012). We therefore predict a negative impact on capital structure.

Age of the firm

Firms that have been operating for many years are attractive clients to banks and creditors. The age of the firm increases the reputation and creditworthiness of a firm. Thus creditors could use the reputation a firm has built over its years in operations to determine the ability of the firm to fulfill its financial obligations (Diamond 1989). Older firms tend to take up more debt and have high debt ratios compared to new firms which have existed in the market for a shorter period of time and are unable to prove the history of their ability to fulfill their financial obligations to creditors. Therefore, we predict a positive relationship between age and capital structure.

\section{Size of the firm}

Smaller firms avoid taking up debt to finance their operations while larger firms tend to have an appetite for debt to finance future projects due to the tax income deductibility of debt as an expense and easier access to credit compared to smaller firms(Castanias 1983). Smaller firms take up less debt to avoid bankruptcy costs associated with increase in debt. Lenders are also cautious when advancing credit to smaller firms due to agency costs which might arise as a result of minimal supervision and regulation of financial decisions implemented by managers of the borrowing firms (Titman and Wessels 1988). Friend and Lang (1988) observed a positive relationship between firm size and capital structure. On the contrary, Cassar and Holmes (2003) found a negative relationship between size and short term debt which 
implies that small firms go for short term debt to cater for operational costs while large firms take up long term debt to finance long term projects. We therefore predict an indeterminate relationship between size and capital structure. The conceptual framework is based on the existing literature as follows;

Exogenous variables

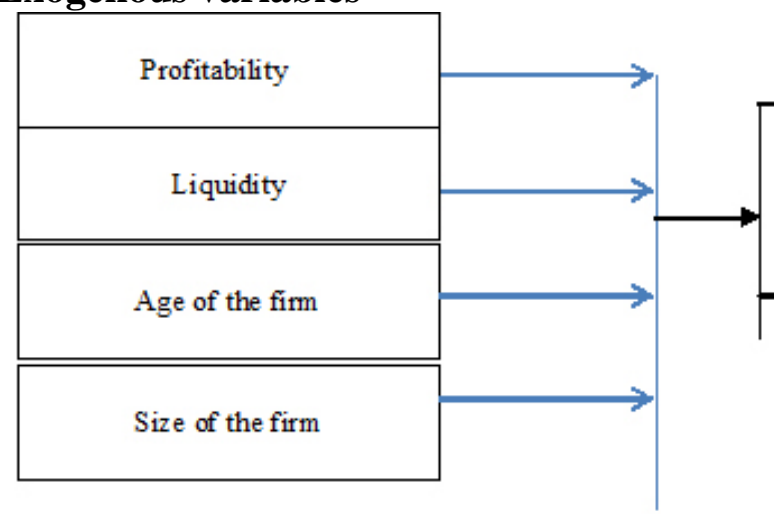

Endogenous variables

\subsection{Model specification}

Consistent with the conceptual framework, the empirical specification seeks to explain the determinants of capital structure in the agriculture industry. For the purpose of estimation, two general linear models are specified as follows:

$L T D_{i t}=\beta_{0}+\beta_{1} R O E_{i t}+\beta_{2} L I Q_{i t}+\beta_{3} A G E_{i t}+\beta_{4} S I Z_{i t}+\mu_{i t}+\varepsilon_{i t}$ $S T D_{i t}=\beta_{0}+\beta_{1} R O E_{i t}+\beta_{2} L I Q_{i t}+\beta_{3} A G E_{i t}+\beta_{4} S I Z_{i t}+\mu_{i t}+\varepsilon_{i t}$

Where $L T D_{i t}$ and $S T D_{i t}$ represents the endogenous variables long and short term debt ratios respectively for the $i$ th firm at $t$ th period. $\beta_{0}$ is the intercept term, the subscripts $i$ and $t$ index firm and time respectively. In addition, the specification also contains an unobservable firm-specific effect $\mu$ and the usual stochastic disturbance error-term $\varepsilon$ following normal distribution with mean 0 and variance $\sigma^{2}$.

$\beta_{i}$ is the slope coefficients where $\mathrm{i}=1 \ldots 4$

$\mathrm{ROE}_{i t}$ is the profitability of firm $\mathrm{i}$ for time period t proxied by return on equity (ROE).

LIQ $_{i t}$ is the liquidity of firm i for time period $t$.

$A G E_{i t}$ is the age of firm $i$ for time period $t$.

$\mathrm{SIZ}_{\mathrm{it}}$ is the size of firm i for time period $\mathrm{t}$.

\subsection{Econometric approach}

The study employed the panel regression model to estimate the determinants of capital structure of agricultural firms in Kenya. Panel data 
combines the cross sectional data or the firm specific effects and the time series data which is the data varying in different time periods. The panel regression model of estimation ensures that omitted variables are controlled thus reducing the chances of biased estimates.

There might be instances of heteroskedasticity due to the difference in variance of the estimates in different time periods. To address this issue, the Breusch-Pagan test was conducted to test the presence of heteroskedasticity in the residual variance. A Langrage multiplier statistic was then calculated and compared with the critical chi-square value ${ }_{x}^{2} 0.005$, $10=25.182$; any values above this level indicated presence of heteroskedasticity. In the presence of heteroskedasticity, the Eicker-HuberWhite standard errors were used to control heteroskedasticity and obtain homoskedastic estimates.

The choice between a fixed and a random effect model was determined by conducting the Hausman test. Random effect model is most suitable for data where the instrumental variables are assumed to be random while the fixed effects model assumes fixed variables across all data thus controlling for omitted variables; it is thus the best model to use for data with unobservable factors which remain unaffected by time. The fixed effect model however, faces the challenge of being unable to estimate within-group variation which may exist in the specific variables and time invariant variables.

Previous studies that have used the fixed effects model to determine factors affecting capital structure include: Abor (2005), Aulova and Hlavsa (2013), Bassey et al. (2014), Muriu (2016). This study also used the Fischer test to test for panel unit root. The Fischer test is commonly used to analyze the non-random relationship between two variables and its p-values are accurate for all data size samples whether large or small whereas the chisquare test results may be inaccurate for small data size samples hence the need to conduct both tests.

\subsection{Dataset and measurement of variables}

This study used annual company data for the period 2010-2015 for listed agricultural firms. The company data was collected from audited financial reports of individual companies, Nairobi Securities Exchange (NSE) quarterly and annual reports and the Kenya Revenue Authority (KRA) database.

Profitability is a crucial indicator of the capital structure decision a firm decides to implement. The profitability of the firm is measured by the return on assets of the firm (ROA) and the return on equity of the firm (ROE). 
Bevan and Danbolt (2002) identified liquidity as the ease of converting assets into cash. The higher the cash flow in a firm, the more liquid it is. The firm's liquidity was measured using the current ratio by dividing current assets by current liabilities.

The age of the firm refers to the number of years that the firm has been in operation. This was measured by taking the number of years in operation. Large firms have more assets than small firms. Consistent with Harford, Mansi and Maxwell (2008), firm size is measured by taking the natural $\log$ of total assets.Capital structure is the debt and equity mix implemented by firms to finance operations. This was measured by long term and short term debt ratios.

\section{Empirical results and discussions}

\subsection{Descriptive Statistics}

Table 4.1 shows that agricultural firms in Kenya have higher proportions of long term debt financing (19.98\%) compared to short term debt financing (9.16\%) in their capital structure composition, suggesting that these firms aim to benefit from the tax shield. The positive values of the capital structure indicates that these companies are in a good position to honour their financial obligations when due.

Table 4.1: Descriptive statistics of variables

\begin{tabular}{l|lllllll}
\hline \multicolumn{1}{l}{} & LTD & STD & ROA & ROE & LIQ & AGE & SIZ \\
\hline Mean & 0.1998 & 0.0916 & 8.9302 & 13.8733 & 5.2645 & 97.3571 & 6.3186 \\
Median & 0.2096 & 0.0755 & 6.55 & 12.5 & 4.56 & 87.5 & 6.415 \\
Maximum & 0.2472 & 0.276 & 61.57 & 85.39 & 18.3 & 146 & 7.21 \\
Minimum & 0.0534 & 0.008 & -11.9 & -14.7 & 1.3 & 58 & 5.2 \\
Std. Dev. & 0.04063 & 0.0655 & 12.4533 & 16.89 & 3.7854 & 32.7726 & 0.567 \\
Skewness & -1.5432 & 1.2379 & 2.0530 & 1.9329 & 1.7257 & 0.4346 & -0.4099 \\
Kurtosis & 5.7106 & 3.7662 & 9.4363 & 9.2671 & 6.3327 & 1.5968 & 1.9968 \\
Jarque- & 15.91 & 9.80 & 24.96 & 23.85 & 18.39 & 16.34 & 5.38 \\
Bera & & & & & & & \\
Probability & 0.2034 & 0.715 & 0.167 & 0.217 & 0.719 & 0.3366 & 0.089 \\
Sum & 8.3922 & 3.848 & 375.07 & 582.68 & 221.11 & 4089 & 265.38 \\
Obs & 42 & 42 & 42 & 42 & 42 & 42 & 42 \\
\hline
\end{tabular}

The mean profitability of the firms measured by the return of assets stands at $8.93 \%$ while the average return on equity is $13.87 \%$ indicating a positive return on investment for investors in this sector, hence making agricultural stocks relatively attractive to potential investors. Even though the mean liquidity ratio (5.2:1) is higher than the recommended value of $2: 1$, signaling positive cash flow available for expansion of product line and increasing inventory, it indicates that these firms are not taking full advantage of investment opportunities in the short run. The average age of agricultural listed firms in Kenya is 97.36 years suggesting only companies 
older than 58 years are listed in NSE raising an alarm on why new firms have not been able to list their stocks in the NSE. The same scenario applies to the size of the firm, with most quoted firms recording large assets base.

The long term debt and firm size have negative skewness values. The short term debt, return on assets, return on equity, liquidity and the age of the firm have positive skewness values. The Jarque-Bera test of normality was conducted and the critical t value (2.490) obtained was below the chi2 value of 22.78, thus indicating the data is normally distributed.

\subsection{Correlation analysis}

Table 4.2 shows that return on assets and return on equity are highly correlated since they both capture the profitability of the firm. The results also indicate that liquidity is negatively correlated to short term debt, implying that firms with free cash flow avoid short term debt. A positive correlation between short term debt, age and the size of the firm implies that large firms which have been operating for a long period of time will have a large appetite for short term debt.

The correlation matrix also shows a negative correlation between liquidity and long term debt implying that highly liquid firms will avoid long term debt and instead opt for retained earnings which is consistent with pecking order theory. The results also indicate a positive correlation between long term debt, return on assets, return on equity, age of the firm and the size of the firm. This implies that older firms are also larger and rely more on long term debt.

\begin{tabular}{l|lllllll}
\multicolumn{7}{c}{ Table 4.2 Correlation matrix } \\
& LTD & STD & ROA & ROE & LIQ & AGE & SIZ \\
\hline LTD & 1.0000 & & & & & & \\
STD & 0.3902 & 1.0000 & & & & & \\
ROA & 0.2098 & 0.0927 & 1.0000 & & & & \\
ROE & 0.2492 & 0.1389 & 0.9721 & 1.0000 & & & \\
LIQ & -0.1384 & -0.5892 & 0.2173 & 0.1629 & 1.0000 & & \\
AGE & 0.4638 & 0.3244 & 0.0014 & 0.0426 & -0.0696 & 1.0000 & \\
SIZ & 0.0854 & 0.0328 & -0.2764 & -0.2444 & -0.5267 & 0.2062 & 1.0000
\end{tabular}

\subsection{Panel unit root tests}

Table 4.3 shows the unit root test. The Fisher-type test, based on the augmented Dickey-Fuller test was conducted to test for stationarity of the data. The p-values obtained from the test were less than 0.05 hence we rejected the null hypothesis which states that all the panels contain unit root. 
Table 4.3: Fisher panel unit root test

\begin{tabular}{|c|c|c|c|}
\hline & & Statistic & p-value \\
\hline $\begin{array}{l}\text { Inverse chi-squared } \\
\text { (14) }\end{array}$ & $\mathrm{P}$ & 32.7523 & 0.0031 \\
\hline Inverse normal & $\mathrm{Z}$ & -2.9831 & 0.0014 \\
\hline Inverse logit (39) & $\mathrm{L}^{*}$ & -3.0582 & 0.0020 \\
\hline $\begin{array}{l}\text { Modified inv chi- } \\
\text { squared }\end{array}$ & $\mathrm{Pm}$ & 3.5438 & 0.0002 \\
\hline
\end{tabular}

\subsection{Hausman test}

The Hausman test is used in panel data to ascertain the most appropriate model. This test was conducted on both the long term and the short term debt models and the results reported in Table 4.4. The p-value obtained from the long term debt Hausman test (0.0143) was significant, therefore the fixed effects model was the most appropriate model.

Table 4.4: Hausman test for long term debt

\begin{tabular}{l|llll}
\hline & $\begin{array}{l}\text { (b) } \\
\text { Fixed }\end{array}$ & $\begin{array}{l}\text { (B) } \\
\text { Random }\end{array}$ & $\begin{array}{l}\text { (b-B) } \\
\text { Difference }\end{array}$ & $\begin{array}{l}\text { sqrt (diag(v_b- } \\
\text { v_B) } \\
\text { S.E }\end{array}$ \\
\hline ROA & 0.0324 & 0.0033 & 0.0292 & 0.02635 \\
ROE & 0.0029 & 0.0035 & 0.0324 & 0.02070 \\
LIQ & 0.0119 & 0.1421 & 0.0230 & 0.01411 \\
AGE & 0.0166 & 0.0070 & 0.1733 & 0.0756 \\
SIZ & 0.0258 & 0.5002 & 0.7578 & 0.1083 \\
\hline
\end{tabular}

Test : Ho: difference in coefficients not systematic

Chi2(5) = (b-B)’ $\left[\left(V_{-} \text {b-V_B }\right)^{\wedge}(-1)\right](b-B)=14.21$

Prob $>$ chi2 $=0.0143$

The Hausman test was also conducted on the short term debt model and the results reported in Table 4.5. The p-value obtained from the test $(0.2481)$ was insignificant but greater than 0.05 . A random effect model was therefore chosen as the most appropriate model to estimate the short term debt model.

Table 4.5 Hausman test for short term debt

\begin{tabular}{l|llll}
\hline & $\begin{array}{l}\text { (b) } \\
\text { Fixed }\end{array}$ & $\begin{array}{l}\text { (B) } \\
\text { Random }\end{array}$ & $\begin{array}{l}\text { (b-B) } \\
\text { Difference }\end{array}$ & $\begin{array}{l}\text { sqrt (diag(v_b- } \\
\text { v_B)) } \\
\text { S.E }\end{array}$ \\
\hline ROA & 0.0324 & 0.0033 & 0.0292 & 0.02635 \\
ROE & 0.0029 & 0.0035 & 0.0324 & 0.02070 \\
LIQ & 0.0119 & 0.1421 & 0.0230 & 0.01411 \\
AGE & 0.0166 & 0.0070 & 0.1733 & 0.0756 \\
SIZ & 0.0258 & 0.5002 & 0.7578 & 0.1083 \\
\hline
\end{tabular}

Test : Ho: difference in coefficients not systematic

Chi2(5) = (b-B)' $\left[\left(\mathrm{V} \_b-V \_B\right)^{\wedge}(-1)\right](b-B)=6.65$

Prob $>$ chi $2=0.2481$ 


\subsection{Estimation results}

Panel regression analysis was conducted on both long and short term debt to test the significance of the independent variables on the capital structure of the firm. Table 4.6 reports the estimation results from equations (1 and 2). The estimated models fit the panel data reasonably well, having fairly stable coefficients. Further, the overall test statistic of the Wald-test shows rejection of the hypothesis that all coefficients are equal to zero. Interesting results emerge in both significant and non-significant findings.

Table 4.6: Estimation results of short term and long term debt

\begin{tabular}{|c|c|c|c|}
\hline \multicolumn{4}{|c|}{ Variant model specifications with robust standard errors } \\
\hline & & Fixed Effects Model & Random Effects Model \\
\hline Variable & Notation & LTD & STD \\
\hline Intercept & & $\begin{array}{l}1.8449 \\
(1.04)\end{array}$ & $\begin{array}{l}0.4061 \\
(4.08)\end{array}$ \\
\hline Return on Assets & ROA & $\begin{array}{l}0.0043 \\
(-0.17)\end{array}$ & $\begin{array}{l}0.0003 \\
(0.13)\end{array}$ \\
\hline Return on Equity & ROE & $\begin{array}{l}-0.0036^{*} \\
(0.39)\end{array}$ & $\begin{array}{l}0.0003 \\
(0.20)\end{array}$ \\
\hline Liquidity & LIQ & $\begin{array}{l}-0.0024 \\
(0.74)\end{array}$ & $\begin{array}{l}-0.0142 * * * \\
(-6.49)\end{array}$ \\
\hline Age of the firm & AGE & $\begin{array}{l}0.0145^{* *} \\
(1.37)\end{array}$ & $\begin{array}{l}0.0007^{* * * *} \\
(3.23)\end{array}$ \\
\hline Size of the firm & SIZ & $\begin{array}{l}-0.0371 \\
(0.87)\end{array}$ & $\begin{array}{l}-0.0500 * * * \\
(-3.36)\end{array}$ \\
\hline Number of observations & & 36 & 42 \\
\hline R - Squared: & & $\begin{array}{lcc}\text { Within } \quad= & 0.4466 \\
\text { Between = 0.3899 } & \\
\text { Overall = 0.1883 } & \\
\end{array}$ & $\begin{array}{lrr}\text { Within } & = & 0.4729 \\
\text { Between= } 0.842 & \\
\text { Overall= 0.6023 } & \\
\end{array}$ \\
\hline F- test/ Wald Chi test & & $\mathrm{F}(5,24)=3.87$ & Wald Chi2(5) = 54.52 \\
\hline Prob> F/ Prob>chi2 & & 0.0103 & 0.0000 \\
\hline
\end{tabular}

Table 4.6 represents regression results of determinants of both long term and short term debt of agricultural firms in Kenya. Estimation for long term debt was done using fixed effects while the short term debt was conducted using random effects. The t-statistics are represented in parentheses while $*, * *, * * *$ represents the significant levels at $10 \%, 5 \%$ and $1 \%$ respectively.

Both the long and short term debt regressions results shows a positive and significant relationship between age of the firm and leverage. These results are consistent with Frank and Goyal (2004), Hovakimian (2004), and Mang'unyi (2011). This is perhaps because firms that have been operational for a long period of time and have either enhanced relationship lending, or may be able to make use of assets acquired over time to serve as collateral for credit.

The proxies for financial performance or profitability in this study are return on assets and return on equity. Estimation results indicates that there is 
a negative relationship between return on equity and capital structure. Previous studies that have arrived at the same findings include Fama and French (2002), Maina (2014) and Kariuki and Kamau (2010). This implies that the the firms may be ploughing back profits which reduces leverage levels. Firms that record high profits are able to easily fund current and future short term projects. Highly profitable firms are able to maintain low debt levels by avoiding taking up new debt which is an additional cost for the firm but instead they use the retained earnings.

The short term regression results illustrate that liquidity, and size were significant determinants of short term debt. The negative association observed between short term debt, liquidity and size of the firm supports Fama and French (2002), Marsh (1982) and Sujay (2015) findings.

The negative link between short term debt and liquidity could be as a result of available cash flow to fund short term operations before resorting to short term debt which is consistent with the pecking order theory and Chen (2004) findings. Highly liquid firms are able to generate high profits therefore reducing the appetite for debt.

The estimation results also establish a negative relationship between leverage and size of the firm. These results are consistent with Castanias (1983), Lang (1988) and Titman and Wessels (1988) who noted that smaller firms avoid debt due to being risk averse and fear of falling into bankruptcy. Intuitively, larger firms are able to take up more debt due to the tax deductibility of income as an expense.

\section{Conclusion}

The main aim of this study was to investigate the determinants of capital structure of agricultural firms in Kenya. The study used annual company data of listed agricultural firms for the period 2010-2015. An empirical model to analyze the impact of profitability, liquidity, age of the firm and size of the firm on the capital structure of listed agricultural firms in Kenya was specified and estimated using both fixed and random effects estimation techniques.

The estimation results reveals a negative relationship between profitability and long term debt and a positive relationship between age of the firm and long term debt. An analysis of the determinants of short term debt indicates that there exists a positive influence of age on debt, while a negative link between liquidity, the size of the firm and short term debt is established.

The negative influence of size on debt implies that as agricultural firms become larger, the weight of debt financing steadily decreases while equity becomes a more important source of finance.Age of the firm has similar implications due to reputation effects. Older firms are therefore able 
to borrow more. The negative influence of liquidity on capital structure implies that firms with positive cash flow can easily finance short term operations and investments without the need of taking up short term debt. Firms should reduce their high liquidity ratios and undertake more short term investments, such as treasury bills or commercial papers, which may ensure that their liquidity is not compromised.

The negative relationship between profitability and leverage implies that agricultural firms in Kenya follow the pecking order theory. Firms could be avoiding higher debt uptake to avoid financial distress associated with bankruptcy costs. Therefore, financial managers should be vigilant before they increase their leverage ratios as this might reduce investments to current and prospective shareholders.

\section{References:}

1. Abor, J. (2005). The effect of capital structure on profitability: an empirical analysis of listed firms in Ghana. The Journal of Risk Finance, 6(5), 438-445.

2. Abosede, A. J \&Oseni, Jimoh Ezekiel (2011). Theoretical analysis of firm and market-specific proxies of information asymmetry on equity prices in the stock markets. Journal of Knowledge Management, Economics and Information Technology, 1(4), 10-10.

3. Adedeji, A. (1998). Does the pecking order hypothesis explain the dividend payout ratios of firms in the UK?. Journal of Business Finance \& Accounting, 25(9-10), 1127-1155.

4. Agha, M., \& Faff, R. (2014). An investigation of the asymmetric link between credit re-ratings and corporate financial decisions:"Flicking the switch" with financial flexibility. Journal of Corporate Finance, 29, 37-57.

5. Alifani, G. A., \&Nugroho, A. B. (2013).Proving Modigliani and Miller Theories of Capital structure: The Research on Indonesia's cigarette companies. International journal of economic sciences, 2013(3).

6. Antoniou, A., Guney, Y.,\&Paudyal, K. (2008). The determinants of capital structure: capital market-oriented versus bank-oriented institutions. Journal of Financial and Quantitative Analysis, 43(1), 59-92.

7. Aulová, R., \&Hlavsa, T. (2013). Capital structure of agricultural businesses and its determinants. Agris on-line Papers in Economics and Informatics, 5(2), 23.

8. Baker, M., and J.Wurgler.(2002). Market timing and capital Structure.Journal of Finance, 57, 1-32. 
9. Bancel, F., \&Mittoo, U. R. (2004). Why do European firms issue convertible debt?. European Financial Management, 10(2), 339-373.

10. Baskin, J. (1989). An empirical investigation of the pecking order hypothesis. Financial management, 18(1), 26-35.

11. Bassey, N. E., Arene, C. J \& Okpukpara, B. C. (2014). Determinants of capital structure of listed agro firms in Nigeria. Economic Affairs, 59(1), 35.

12. Berger, A. N., \& Di Patti, E. B. (2006).Capital structure and firm performance: A new approach to testing agency theory and an application to the banking industry. Journal of Banking \& Finance, 30(4), 1065-1102.

13. Bevan, A. A., \&Danbolt, J. (2002). Capital structure and its determinants in the UK-a decompositional analysis. Applied Financial Economics, 12(3), 159-170.

14. Bose, D. C. (2010). Fundamentals of Financial management.PHI Learning Pvt. Ltd.

15. Bradley, M. a. (1984). On the existence of an optimal capital structure: theory and evidence. The Journal of Finance, 39, 857 878.

16. Brealey, R. A., Myers, S. C., \& Myers, S. (2003). Financing and risk management. McGraw Hill Professional.

17. Cassar, G. \& S. Holmes. (2003). Capital structure and financing of SMEs: Australian evidence. Journal of Accounting and Finance, 43, 123-47.

18. Castanias, R. (1983). Bankruptcy risk and optimal capital structure. The Journal of Finance, 38(5), 1617-1635.

19. Chen, J. J. (2004). Determinants of capital structure of Chinese-listed companies. Journal of Business research, 57(12), 1341-1351.

20. Copeland, T. E., Weston, J. F., \&Shastri, K. (1983). Financial theory and corporate policy (3). Reading, Mass.: Addison-Wesley.

21. DeMarzo M. Peter, Michael J. Fishman. (2007).Review of Financial Studies, 20 (6), 2079-2128.

22. Diamond, D. W. (1989).Reputation acquisition in debt markets. Journal of political Economy, 97(4), 828-862.

23. Donaldson, G. (1961). A study of corporate debt capacity. Boston: Harvard Business School.

24. Fama, E. F., \& French, K. R. (2002).Testing trade-off and pecking order predictions about dividends and debt. Review of financial studies, 15(1), 1-33.

25. Fan, J. P., Titman, S., \&Twite, G. (2012).An international comparison of capital structure and debt maturity choices.Journal of Financial and Quantitative Analysis, 47(1), 23-56. 
26. Frank, M.Z., \&Goyal, V.K. (2007). Capital structure decisions: Which factors are reliably important? Financial Management, 38(1), 1-37.

27. Frank, M. Z., \&Goyal, V. K. (2004). The effect of market conditions on capital structure adjustment. Finance Research Letters, 1(1), 4755.

28. Friend, I., \& Lang, L. H. (1988).An empirical test of the impact of managerial self-interest on corporate capital structure. The Journal of Finance, 43(2), 271-281.

29. Graham, J.R., Harvey, C.R. (2001): The theory and practice of corporate finance: Evidence from the field. Journal of Financial Economics, 60(2-3), 187-243.

30. Gharaibeh, A. (2014). Capital structure, liquidity, and stock returns. European Scientific Journal, 10(25).

31. Hadlock, C. J., \& James, C. M. (2002). Do banks provide financial slack?. the Journal of Finance, 57(3), 1383-1419.

32. Hamilton, R. T., \& Fox, M. A. (1998).The financing preferences of small firm owners. International Journal of Entrepreneurial Behavior \& Research, 4(3), 239-248.

33. Harford, J., Mansi, S. A., \& Maxwell, W. F. (2008). Corporate governance and firm cash holdings in the US. Journal of Financial Economics, 87(3), 535-555.

34. Hennessy, C., \& Whited, T. M. (2005).Debt Dynamics.Journal of Finance, 60(3), 1129-1165.

35. Hovakimian, A., Hovakimian, G., \&Tehranian, H. (2004). Determinants of target capital structure: The case of dual debt and equity issues. Journal of financial economics, 71(3), 517-540.

36. Hijazi, S. T., \& Bin Tariq, Y. (2006). Determinants of capital structure: A case for Pakistani cement industry. Journal of Economics, 11(1), 63-80.

37. Huang, R., \& Ritter, J. R. (2009). Testing theories of capital structure and estimating the speed of adjustment. Journal of Financial and Quantitative analysis, 44(02), 237-271.

38. Jensen M and Meckling W. (1976). Theory of the firm: Managerial behaviour, agency cost and ownership structure. Journal of Financial Economics, 3(4), 303-431.

39. Kariuki, S. N., \&Kamau, C. G. (2014). Determinants of corporate capital structure among private manufacturing firms in Kenya: A survey of food and beverage manufacturing firms. International Journal of Academic Research in Accounting, Finance and Management Sciences, 4(3), 49-62. 
40. Korajczyk, R. A., Lucas, D. J., \& McDonald, R. L. (1991). The effect of information releases on the pricing and timing of equity issues. Review of financial studies, 4(4), 685-708.

41. Kraus, A., \&Litzenberger, R. H. (1973).A state-preference model of optimal financial leverage. The journal of finance, 28(4), 911-922.

42. Lace, N., Peleckienè, V., \&Bistrova, J. (2011). The influence of capital structure on Baltic corporate performance. Journal of Business Economics and Management, (4), 655-669.

43. Leary, M. T., \& Roberts, M. R. (2005). Do firms rebalance their capital structures? The Journal of Finance, 60(6), 2575-2619.

44. Lemmon Michael L., Zender Jamie F. (2010). Debt capacity and tests of capital structure theories. Journal of Financial and Quantitative Analysis, 45(5), 1161-1187.

45. Mac anBhaird, C. (2010).The Modigliani-Miller proposition after fifty years and its relation to entrepreneurial finance. Strategic Change, 19(1-2), 9-28.

46. Mang'Unyi, E. E. (2011). Ownership structure and Corporate Governance and its effects on performance: A case of selected Banks in Kenya. International Journal of Business Administration, 2(3), 2.

47. Maina, L., \&Ishmail, M. (2014). Capital Structure and Firms Performance in Kenya: Evidence from firms listed at the Nairobi Securities Exchange. International Journal of Social Sciences and Entrepreneurship, 1(11), 1-14.

48. Marsh, P. (1982). The choice between equity and debt: An empirical study. The Journal of finance, 37(1), 121-144.

49. Mazur, K. (2007). The determinants of capital structure choice: evidence from Polish companies. International Advances in Economic Research, 13(4), 495-514.

50. Meier, I., \&Tarhan, V. (2007).Corporate investment decision practices and the hurdle rate premium puzzle.Chicago:HEC Montreal and Loyola University.

51. Miller, MH (1977). 'Debt and taxes'.Journal of Finance, 32, 261-76.

52. Modigliani, F., \& Miller, M. H. (1958). The cost of capital, corporation finance and the theory of investment. The American economic review, 261-297.

53. Modigliani. F and Miller.M (1963). 'Corporate income taxes and the cost of capital: A correction’. American Economic Review, vol. 53, pp. 443-53.

54. Morris, J. R. (1976). On corporate debt maturity strategies. The Journal of Finance, 31(1), 29-37. 
55. Muriu, P. W (2016).Microfinance performance. Does financing choice matter? European Journal of Business and Management, 8(33),77-93.

56. Myers, S. C. (1984). The Capital Structure Puzzle.Journal of Finance, 39, 581-582.

57. Myers, S. C., \&Majful, N. S. (1984).Corporate financing and investment decisions when firms have information that investors do not have. Journal of financial economics, 13(2), 187-221.

58. Ozkan, A. (2001). Determinants of capital structure and adjustment to long run target: evidence from UK company panel data. Journal of Business, Finance \& Accounting, 28(1-2), 175-198.

59. Pagano, P. and Schivardi, F. (2003), Firm Size Distribution and Growth. The Scandinavian Journal of Economics, 105: 255-274.

60. Rajan, R. G., Zingales L. (1998).Financial dependence and growth.The American Economic Review, 88(3), 559-586.

61. Republic of Kenya. (2010). Agricultural Sector Development Strategy (ASDS) 2010-2020. Nairobi, Kenya: Government Printer.

62. Sarlija, N., Harc, M. (2012). The impact of liquidity on the capital structure: a case study of Croatian firms. Business Systems Research, 3(1), 30-36.

63. Scherr, F. C., \& Hulburt, H. M. (2001).The debt maturity structure of small firms.Financial management,30(1).

64. Serghiescu, L., \&Văidean, V. L. (2014). Determinant factors of the capital structure of a firm-an empirical analysis. Procedia Economics and Finance, 15, 1447-1457.

65. Stern, J. M., \& Chew JrJr, D. (Eds.). (2003). The revolution in corporate finance. Wiley-Blackwell.

66. Stiglitz, J. E. (1969). A re-examination of the Modigliani-Miller theorem. The American Economic Review, 59(5), 784-793.

67. Sujay, M., \&Guhathakurta, K. (2015). Product market performance and capital structure: A Hierarchical Bayesian semi-parametric panel regression model. MPRA Paper 62517, University Library of Munich, Germany.

68. Titman, S., \&Wessels, R. (1988).The Determinants of Capital Structure Choice.Journal of Finance, 43, 1-19.

69. Villamil, A. P. (2008). The Modigliani-Miller Theorem. The New Palgrave Dictionary of Economics, Second Edition.Eds. Steven N. Durlauf and Lawrence E. Blume. Palgrave Macmillan, 6.

70. Warfield, T. D., Weygandt, J. J., \&Kieso, D. E. (2007). Intermediate Accounting: Principles and Analysis. Wiley Global Education.

71. Welch, I. (2004). Capital structure and stock returns. Journal of political economy, 112(1), 106-131. 